\title{
The medical market around 1850
}

The 'market for medical goods and services' has consumers and suppliers. Let us start with the consumers for, after all, 'no sufferers, no doctors' (Porter 1985:182). It is difficult to obtain information from people about their diseases and their treatment. This is true for modern-day anthropologists (Jordaan 1985:11; Courtens 2008:7) and definitely applies to the historical sources dating from the period around 1850 in the Dutch East Indies, when both schools highlighted in this book did not yet exist. Nevertheless, the orally transmitted data do give us an idea of the medical market in the mid-nineteenth century.

\section{THE CONSUMERS}

All the inhabitants of the archipelago were consumers of 'products and services' from the medical market at some time or another. Specific figures for the number of inhabitants of the Dutch East Indies are lacking, but according to an estimate from 1850, the population of Java (and Madura) was 9.5 million and the Outer Islands 10.5 million. ${ }^{1}$ In Java and Madura alone there was a large diversity of population groups: Javanese, Sundanese, Madurese, Chinese, Arab, Malay and Eurasian. These groups spoke different languages and had their own religions and concepts about health, disease and treatment. Religion and world views determine how health and disease are defined and thus the way in which they are dealt with. If people do not consider something a disease, they are unlikely to search for treatment and thus use products or services from the medical market. 
The vast majority of the indigenous population of Java was Islamic, although it was said that 'Java was not Islamized, but Islam was Javanized'? many local customs and practices were adopted from earlier Javanese religions, like animism, Hinduism and Buddhism (Indonesia 1971:1225). In the Javanese concepts of health and disease, the various religious influences can be recognised. ${ }^{3}$ Most historical sources, including an official in the Indies civil service, H.A. van Hien, and the ethnographer, J.P. Kleiweg de Zwaan, ascribed a dominant position to the animistic substrate in the Javanese concepts about health and disease. ${ }^{4}$

\section{ANIMISM}

According to animistic belief, not only people have souls, but animals, plants and objects do as well. This soul is thought to be made of a delicate material referred to as 'soul substance' (Kruijt 1906:2; Kreemer Jr. 1915:16). The soul provides the life force; a reduction of soul substance leads to disease and ultimately to death. An individual's soul substance can decrease as a result of strong emotions like a deep longing for someone who has died, or under the influence of sorcery, or when an angry spirit or other supernatural creature robs the soul (Kleiweg de Zwaan 1916:1707). Sambang, an angry spirit roaming in search of victims and acting as the personification of unhealthy winds and vapours, apparently caused many diseases. With offerings, incense and other magical methods, he could be appeased (Van Hien 1896:10). Conflicts between two angry spirits could cause an epidemic. The local population ascribed the epidemic on Central Java in 1847 to a quarrel between two mountain spirits. ${ }^{5}$ On Buru (Maluku), the inhabitants even considered the Dutch capable of sending an angry spirit to bring disease (Kleiweg de Zwaan 1910:254). People considered the Dutch that powerful, but also that evil.

$2 \quad$ Penders 1977:236. Ricklefs (2007:30) talks about 'the “mystic synthesis" of Javanese Islam'.

3 In the year 1979 - at the ASEAN mental health teaching seminar in Jakarta - people did not dare to comment about whether there were still traces of the Unani, Ayurveda or Chinese medicine in the treatment methods of traditional healers in Indonesia, Specific recommendation 1983:6.

4 Van Hien 1896, I:1-2. P.J. Veth (1875:311) ascertained that fundamentally the majority of Javanese remained faithful to their old nature worship. Modern anthropologists such as Mark Woodward (1985:1011) and Roy Jordaan (1985:153) recognised the great importance of the Hindu influences from southern India.

$5 \quad$ Letter from Rochussen to Baud 25-8-1847 no. (25) 64; Baud 1983b:275; cause is angry spirits (the shades of their relatives), Jeronymus 1849:7. 
The origin of disease was ascribed to worms, poisoning, magic and winds. ${ }^{6}$ Catching cold, for example, was a consequence of the wind, masuk angin (literally entrance of the wind). According to health officer C.G.C.F. Greiner (1875:178), the inhabitants of the archipelago understood the infectious nature of many diseases. They talked about disease germs and linked colour and contamination. When visiting smallpox patients, he had to wear white clothes preferably, and definitely not black ones. He did not dismiss this as nonsense and argued for further investigation. Civil servant J. Kreemer Jr. (1915:10) confirmed that the natives were aware of the infectious nature of a number of diseases, as evident from a range of prophylactic measures such as isolating the sick and burning their clothes.

The natives' behaviour around disease was influenced by their concepts about its causes. They rarely complained about external diseases or wounds, in the experience of civil physician J.H.F. Kohlbrugge (1910:812). Health officer J. Haga (1880:28) confirmed that this was a known fact (see also Van Bergen 2007:899). With internal diseases, however, a native soon felt very ill. The spirit had taken part of his soul substance and that worried him so much that he felt it was impossible to go on working (Kohlbrugge 1910:81-2). This partly matches the findings of the modern-day anthropologist Adriaan S. Rienks and the sociologist Purwanta Iskandar (1988:76-9) that the Javanese distinguish between severe and simple diseases. The severity is not determined by the nature, but by the cause. The aetiology of severe diseases can be inappropriate social or religious behaviour, or transgression of the adat (indigenous customs and law) or the revenge of an angry spirit. A serious injury after a fall from a tree is an example of a simple disease because the cause is just carelessness. Simple diseases can mostly be treated by the person on his/her own, but for severe diseases a healer must be called in.

\footnotetext{
$6 \quad$ Three causes (spirits, winds and worms) were listed in Geneeskundigen (Inlandsche) 1917:768; magic in Geneeskundigen (Inlandsche) 1939:141. Kreemer Jr. (1908:446) described how worms could cause disease: from birth, every body harbours various worms. Normally, they do no harm, but if someone eats bad food or drinks contaminated water, then the worms look for an exit and make the person sick (for example, diarrhoea, cholera, vomiting).
} 
ISLAM

This blending of Islam with older religious concepts could explain why the Islamic practice of medicine, Unani, never gained a foothold in Java. Nevertheless, several of the animistic terms described above can also be found in Unani medicine. There are three major medical traditions, one from Greece (the Galenic-Islamic, also known as Arabic-Persian or Unani; Dunn 1977:145), one from the Indian subcontinent (Ayurveda) and one from China. They have several fundamental terms in common because all three are based on general physiological and cosmological concepts. They all use the theory of humours with the contrasts warm-cold, dry-wet and male-female. Imbalance causes disease. The balance is affected by age, gender, diet and climate. To form a diagnosis, you observe the physical symptoms and the environment. Therapy involves physical manipulation, diet and medication. These three major medical traditions promote belief in a close relationship between the balance in the human body, the local community and the cosmos (Leslie 1977:4).

On Java there were orthodox Islamic centres just like elsewhere in the archipelago, including Banten, Kudus and Demak. The arrangement of the Koran does not make it easy to distil a clear vision of disease and health from it. Certain quotations from the Prophet suggest to many pious Muslims that suffering is a religious virtue and disease a sign of saintliness. 'Whoever dies in a sickbed, dies the death of a martyr' is one such quotation that does not encourage undergoing medical therapy. In addition, the conviction that illness comes from Allah can be a hindrance to seeking treatment. The faithful may submit to a doctor's ministrations as long as they believe that Allah ultimately decides about suffering and healing. But there are also quotations from the Prophet that invite taking action, for example that Allah has not sent any disease to humanity without the appropriate medical remedy (Bürgel 1977:54-9). Some representatives of Western medicine, such as former health officer N.P. van der Stok (1885:158-9) and the native doctor Goelam (1926:327), hoped with this last quotation to convince natives to submit to Western medical treatment. 


\section{THE SUPPLIERS}

In the vast majority of cases, the patient and his/her family decided on the diagnosis and the treatment. This had consequences for the supply side of the medical market. Most of the time, patients cared for themselves. This was so normal that it hardly ever needed to be mentioned in the sources. The population 'doctored' itself in a variety of ways: diet (to increase the soul substance; Kruijt 1906:50), applying home remedies or purchased medicines, burning incense, making sacrifices, or massage (Jordaan 1985:214). People also organised communal rituals such as a sacrificial meal, selamatan, or a prayer session to ward off diseases. ${ }^{7}$ The latter was practised when cholera threatened the Amuntai district (Kalimantan), and also in Jakarta (De Munnick 1912:55; Abeyasekere 1987:204). As a preventative measure, some Chinese in Jakarta invited dragon dancers to perform, as the cholera demon was apparently afraid of them. ${ }^{8}$

The suppliers formed a heterogeneous grouping, just like the consumers, each with its own definition of disease, health and healing, and thus its own manner of treating 'sufferers'. The indigenous healers, the dukun, made up the largest group, within which the dukun bayi, the midwives, had their own position. Other suppliers included the herbalists and herbal sellers, the Chinese and European doctors and ultimately the hospitals.

\section{DUKUN}

Unfortunately, there is not a single source from this period written by or quoting a dukun or in which natives give their idea of them. ${ }^{9}$ We view the dukun only through the eyes of the Europeans. We can only guess at the number of dukun in 1850; in 1884 the Colonial Report stated that 11,000 worked on Java and Madura. Along with the dukun who dealt with health

\footnotetext{
7 In Jakarta in 1883 in the cholera season, described in Sinar Terang, Abeyasekere 1987:204.

$8 \quad$ Pembrita Betawi 12-7-1901 named by Abeyasekere 1987:204.

$9 \quad$ Bambang Subroto (1983:134-5) distinguishes the following traditional healers in modern Indonesia: along with dukun, sinse (use Chinese medicine), tabib (use Unani medicine), paraji (at births), acupuncturists, masseurs, tukang jamu (herbal seller). In Central Java dukun is equivalent to a TBA (traditional birth attendant), and the other indigenous healers are specified by kyai (Sarwoko, Ruslan Adji and Subodro 1983:231). On Bali, they are called balian manak.
} 


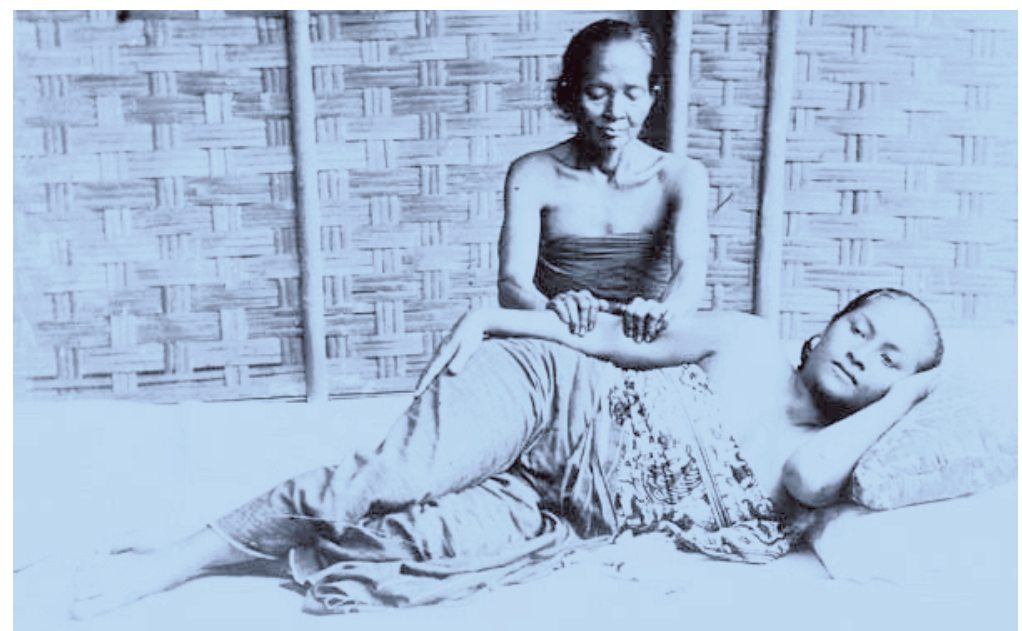

Dukun specialised in massage and her client. (photo collection KIT 60009249)

and disease, some identified people guilty of theft, determined good days for a wedding, and other affairs. The medical dukun were often specialised: some treated only internal diseases, others were adept in massage, and others were experts in circumcision or splinting. ${ }^{10}$

Dukun were almost always old men and women. ${ }^{11}$ Their scope of activity was in principle their own village, but good dukun would attract patients from the surrounding region. They were paid in money, goods or services. The civil servant E. Francis stated in his memoirs that in Lampung (Sumatra), a male dukun received 6-12 'oewang' (ten-cent coin) for circumcising a boy; for girls the female dukun received 3 oewang or a skein of yarn of the same value (Francis 1856:181). At first sight, it appears that women were being paid less than men even back then, but female circumcision was a much less complex procedure than the male version. ${ }^{12}$ Modern scientists have ascertained that dukun on West Java, Madura and Sumba could not live from the payments for their services

1o Classification of dukun by Geertz 1960; Koentjaraningrat 1979; Parsudi Suparlan 1978; Boedhihartono 1982; Jordaan 1985.

1 Crawfurd 1823:323. Veth (1875:485) assumed incorrectly that a dukun was rarely a man and usually a woman. Also according to Bleeker (1844b:267 note 1), dukun were mostly old women.

12 Circumcision of girls was a small cut in the outer labia majora and thus completely different from the clitoridectomy practised in some African countries. 


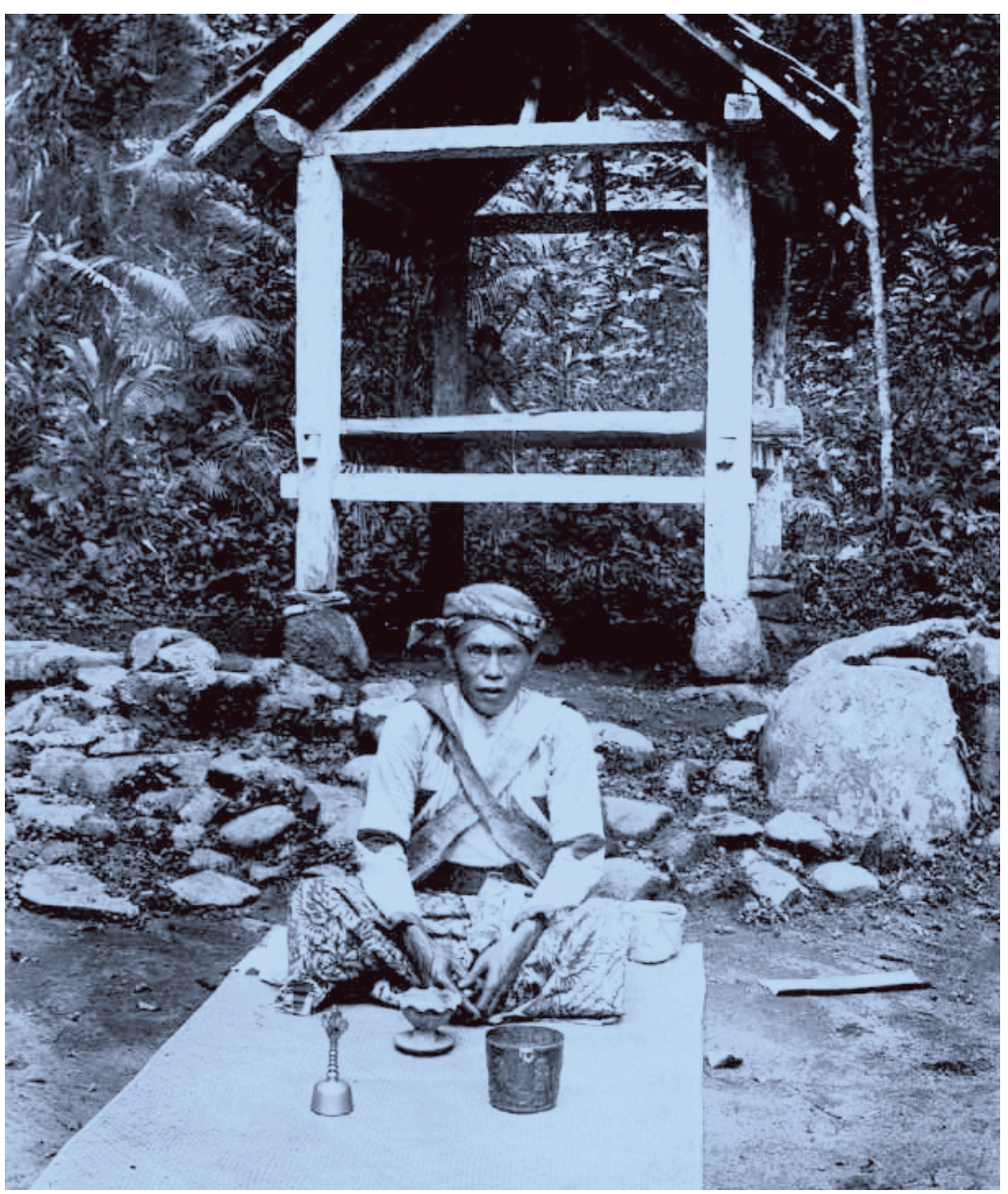

Dukun from Kandangan, near to Lumajang (East Java). He is an elderly man sitting on a mat with a mortar among other tools. The photo was taken about 1925. (photo collection KITLV 36274)

and thus had to carry out other activities as well, such as farming. ${ }^{13}$ The professionalism of the dukun was based on magic, namely pronouncing the correct formulas and conducting rituals, and empiricism, applying certain techniques and medicinal herbs.

13 Boorsma 1913:2; Lubis, Borkent-Niehof and Pudji Astuti 1973; Jordaan 1985:171; Mitchell 1982:1. 


\section{KNOWLEDGE}

The dukun gained their knowledge from an experienced dukun and from extensive practice. This information was primarily transferred orally, often by a family member. J. Kreemer (1882:590, note 16), missionary in Malang, wrote that a dukun bayi only passed on her magic formulas to her children or grandchildren when her end was near. The ethnographer L.Th. Mayer (1918:5) described the same tradition: Dukun learned their business or profession from their mothers or elderly family members and enriched their knowledge through personal experience. None of the sources reported that the dukun obtained information from the usada or wisuda, old Javanese texts about the art of healing and treating patients. ${ }^{14}$ For Europeans, it was difficult to uncover the magical knowledge of the dukun: 'The secretive darkness, in which the dukun hides her work, makes it very difficult to obtain reports about it'. ${ }^{15}$ To his regret, the orientalist H.C. Klinkert found that the Malay healers would not relinquish their writings, even for payment. They had their own language, just like the physicians and pharmacists in the Netherlands had 'dog Latin'. For Klinkert (1869:182-4) this was proof that the Malay medicine was not inferior. Mayer (1918:29) ultimately discovered that dukun are forbidden to reveal their formulas to the uninitiated. He suspected that the dukun do not understand what they say anyway. After a study lasting ten years, civil servant H.A. van Hien (1896:v) succeeded not only in providing a list of a large number of spirits, but also the incantations against the influence of evil spirits. According to him, the natives kept this knowledge secret because Europeans had too little respect for the adat.

\section{METHOD}

The dukun's method aimed at restoring the patient's harmony with a combination of magical and empirical knowledge. First of all, they made a diagnosis. This was accomplished through various sorts of calculations or meditation or by analysing the symptoms (Koentjaraningrat 1979:42). Then they would attempt to drive away the evil spirit that had disturbed

\footnotetext{
${ }^{14}$ Koentjaraningrat 1979:37-43. Connor (1983:59) defines usada as Javanese-Balinese texts about medicine, magic and mysticism.

${ }_{15}$ Stratz 1897:42. The first physician in Semarang, J.A. van Dissel (1869:375), found that dukun were very reluctant to hand over their writings.
} 
the balance. For example, for headache, earache or toothache, prayers had to be said on Saturday to Sambang while burning incense. While doing this, one had to hold a pinang nut in the hand ${ }^{16}$ and repeat the same sentence into it three times. ${ }^{17}$ It was thought that the nut, which was thrown away afterwards, would take the disease with it. For rheumatism and joint pain, they turned again to Sambang and burned incense, but now on Monday and speaking another text (Van Hien 1896:9-10). If the diagnosis ascribed the disease to a loss of soul substance, then the dukun would try to replenish it with some taken from other people, plants or animals. While chanting incantations, they sprayed the afflicted body parts or objects or smeared them with clean spit or chewed herbs. ${ }^{18}$ Human excretions like spit and urine contain soul substance from the person in question (Kreemer Jr. 1915:15-6). Treatment with saliva was also done by laypeople. ${ }^{19}$ Almost everywhere throughout the archipelago, people were familiar with spraying with sirih-spit, from chewing a well-known plum. The red colour of the saliva leads to the healing effect, as the spirits are afraid of it. ${ }^{20}$ Kreemer Jr. (1915:13) pointed out that this practice was not so strange because the volatile oil of the sirih leaves contains a strongly antiseptic substance, chavicol, which was also recommended in European medicine. Therefore, the physician C.L. van der Burg (1887:420) was enthusiastic about applying sirih to cover wounds. Some spices were unsuitable for strengthening the weakened soul substance of the patient because of their form, flavour or name and were therefore forbidden (Kruijt 1918:83). Another treatment method involved the use of amulets and incantations. Amulets are often small objects like a piece of clothing, hair or nail clippings from the 'sufferer' over which the dukun has uttered magical incantations, and then the sufferer has to wear them on the body (Koentjaraningrat 1979:44). Operations were never undertaken by the dukun as surgery was said to be forbidden (Mayer 1918:5-6).

The dukun were also concerned with the welfare of the community, not just that of the individual. When smallpox broke out in a village, they went from house to house distributing pieces of lemon to protect against the evil spirit that had caused the smallpox (Kreemer Jr. 1915:12).

\footnotetext{
16 Areca catechu L., a palm, the nuts of which were used in the sirih-plum.

17 'Si keteq, doenoengmoe ana ing lodojong!' I have not been able to discover the meaning of this sentence.

18 Bleeker 1844a:474-5, note 1; Kruijt 1906:62; Kreemer Jr. 1915:13, $20,22$.

19 A caregiver treated the crown prince of Karangasem (Bali) in this way for motion sickness (Djelantik 2001:31).

2o Bleeker 1844a:474-5, note 1, 1844b:267; Kreemer Jr. 1915:13.
} 
Another example is cleaning the village of evil influences (bersih desa). ${ }^{21}$ The dukun would call on supernatural forces, and the villagers would clean their houses and remove weeds from the yards. This certainly had a preventive effect because it made the village less attractive to mosquitoes, ticks and snakes.

\section{REMEDIES}

Remedies occupied a key role in the dukun's practice; they consisted of vegetable and animal components and minerals. ${ }^{22}$ In the formulas the herbs were sometimes given other names than those used in daily life, probably to keep the knowledge secret and for fear that the use of common names would reduce their power (Pigeaud 1967:265). A.G. Vorderman (1886:3), the Civil Medical Service inspector on Java and Madura, ascertained that the Europeans were only familiar with the indigenous medicines from Java. When the sources mention local medicines, they thus actually refer just to Javanese ones.

Vorderman (1894:242-50) not only described the various medicines and their effect, he also examined in detail the explanations the dukun gave for the result. They were based on the doctrines of transmigration and of signatures. The transmigration doctrine posits that some medicines can transfer their properties to the body of the user. For example, many Javanese avoided eating the meat of white water buffalos for fear of losing the pigment in areas of their own body. A weak person would become stronger if he ate the sturdy, fibrous stems of a certain plant. ${ }^{23}$ Dysentery sufferers would feel better if their faeces smelled normal; therefore, the dukun incorporated leaves in their formula that spreads the smell of normal faeces. ${ }^{24}$ The consumption of a cicak, a small lizard, ${ }^{25}$ was a remedy against leprosy because of its ability to regrow its lost tail. ${ }^{26}$ The transmigration doctrine is also evident in a treatment method involving the dukun writing magical formulas from an usada or the Koran

\footnotetext{
${ }^{21}$ According to Parsudi Suparlan (1978:206) these rituals were abolished as they apparently conflicted with Islam; according to Heringa (2007:25) they still exist. Koentjaraningrat 1979:48 mentions bersih dhusun [cleaning of the village].

${ }^{22}$ Boorsma (1913:39-42) describes the indigenous remedies of animal origin.

23 Sidagori lelaki, a Sida species from the Malvaceae famiy.

${ }^{24}$ Daon kesimboekan, also known as daon kentoet, Paederie foetida L., Rubiaceae.

25 Hemidactylus frenatus Schl.

26 Vorderman 1894:242-50 gives 30 examples of the transmigration doctrine in total.
} 
on a cloth. The cloth was then washed, and the sufferer had to drink the rinse water so he would absorb the power of the formulas through the water (Kleiweg de Zwaan 1910:93; Koentjaraningrat 1979:43).

According to the doctrine of signatures, the healing power is based on a likeness of form (similia similibus). The external features of a natural product's form and colour reveal which diseases it can help cure. For example, the turmeric root is prescribed for jaundice, and the blood-red fungus for bleeding. ${ }^{27}$ Vorderman pointed out that the effect, according to the transmigration doctrine, should actually be reversed: the fungus should cause bleeding and turmeric root induce jaundice. Kreemer Jr. (1915:36) referred to the application of red silk for nosebleeds by 'our ancestors' and of red semi-precious stones by Arabs, Europeans and natives for haemorrhaging as examples of the doctrine of signatures. They show that this theory was not specific to the Dutch East Indies, nor even to Asia. In Europe as well, the doctrines of transmigration and signatures were influential. ${ }^{28}$ In Holland and Flanders, even at the beginning of the twentieth century people hoped to speed up a drawn-out labour with the rose of Jericho. This 'petrified' plant opens up when placed in water. ${ }^{29}$

The natives and the dukun also used a classification into warm and cold (Van Dissel 1869:375; Waitz 1829:2). The ratio must be in balance and could be restored if needed by treating 'warm' diseases with 'cold' medicines and vice versa. 'Warm' medicines do not have to be warm to the touch (Jordaan 1985:207). Health officer P. Bleeker (1844a:458), the first director of the dokter djawa school, described how the personal physician of Jan Pieterszoon Coen, Bontius, was convinced that warm rice would damage the central nervous system and could lead to blindness. The Javanese and Malays also believed this, and never ate rice warm. Bleeker considered warm rice to be harmless, but he still felt it was better to eat rice cold. He thought that it was better to eat food cold in general. J. Kreemer (1882:580) stated that many spices and drinks were forbidden for pregnant women because they were 'warm' and could lead to a miscarriage. Many scientists now believe that the classification into 'warm' and 'cold' arrived in the archipelago through Persian and Indian

${ }_{27}$ Respectively, Temu lawak - rhizome (Curcuma longa L.) and Jamur rimpes (Lycoperdon giganteum Batsch and L. kakavu Lév).Vorderman 1894:251 lists 7 examples of the doctrine of signatures in total. Boorsma 1913:39 lists others.

${ }_{28} \quad$ Kleiweg de Zwaan (1910:87-97) gives several examples of this.

29 Kleiweg de Zwaan 1910:89; Aluin Museum, Ghent (Belgium). 
influences. ${ }^{30}$ The anthropologist Roy E. Jordaan (1985:206, 1988:152-5) predicates an Austronesian medical tradition existing before the Hindu era because in Indonesia and Malaysia other warm-cold distinctions were made regarding sexuality and pregnancy that are not found in the Galenic tradition.

\section{EUROPEANS AND INDIGENOUS MEDICINAL HERBS}

Europeans have a long tradition of lively interest in indigenous medicinal herbs, starting with Bontius. This trend was continued in the nineteenth century by the Semarang municipal physician, F.A.C. Waitz. In his book, Practische waarnemingen over eenige Favaansche geneesmiddelen (Practical observations on some Javanese medicines, 1829), he reported the effect of various local remedies along with the description. He had tried them out on European and native patients and once on himself (Schoute 1936:122). G. Wassink, the head of the Medical Service, and Vorderman published a series of articles about indigenous medicinal herbs. ${ }^{31}$ The third volume of the standard work by Van der Burg, De geneesheer in Nederlandsch-Indië (The physician in the Dutch East Indies), entitled Materia indica (1885), was entirely devoted to indigenous herbs. ${ }^{32}$ Prominent European physicians were clearly interested in them.

The study of local medicines had a practical significance as well as a scientific one for Europeans. According to Waitz, in his time - around 1830 - only two-thirds of the remedies included in the Pharmacopoea Belgica ${ }^{33}$ were available in the Indies pharmacies, and a quarter of them had spoiled or were no longer useful (Waitz 1829:iii; Selberg 1841:4434). Alternatives for the medicines from Europe were thus very welcome. The colonial government was thoroughly aware of this. The Medical Service regulations of 1827 charged the health officers with examining

\footnotetext{
3o Jordaan 1985:206 cites D.V. Hart (1969), L. Manderson (1981), Hiroko Horikoshi-Roe (1980).

$3_{1}$ Wassink, 'Onderzoekingen naar de geneeskrachten van inlandsche geneesmiddelen', GTNI 185457 (2:431-45; 3:225-35, 326-30, 520-4; 4:569-75, 749-51, 985-96; 5:813 etc.; Vorderman, 'Inlandsche geneesmiddelen', Tijdschrift voor Inlandsche Geneeskundigen 1894-1902 (2:17-22; 3:17-21; 4:1-6; 6:1-9; part 5 is missing; 8:49-55; 10:101-9.

$3^{2}$ Vorderman (1886) belittled this work that he felt was written behind a desk on the basis of books without any experience of the practice and thus was incomplete and full of inaccuracies. He even went so far as to accuse Van der Burg of plagiarism. Groeneveldt (1886:281-90) was very critical of the Chinese formulas; he felt it would have been better to have left them out.

33 At that time the Netherlands and Belgium were one country.
} 
the indigenous therapies and the dukun's methods. If they encountered anything useful, they were required to inform their superiors (Ind. Stb. 1827 no. 68 art. 52). Even in the 1880s the members of the Vereeniging tot Bevordering der Geneeskundige Wetenschappen in NederlandschIndië - European physicians - exchanged information during meetings about where to obtain the best indigenous herbs in Jakarta: from Ms. Schuler on Gunung Sahari or from Ma doekoen Tonggo in kampong Kemayoran. ${ }^{34}$

\section{EUROPEANS ABOUT THE DUKUN}

The Europeans appreciated the dukun's knowledge of medicinal herbs partly for practical reasons. In contrast, the dukun's grasp of anatomy and the functioning of the human body was considered pitiful (Waitz 1829:1; Broekmeyer 1856:39). The following quotation from the Colonial Report of 1849 clearly shows how widespread this condescending attitude was among Europeans:

Even among those who claim to be healers (dukun) and as such gain a great reputation (mostly women), when administering medicines they trust blindly in their science, which states that when certain medicines are applied in certain conditions, the patients recover. [...] It is self-evident that so limited an empirical method, although it may in some of the more common diseases (e.g., of the bowels) have coincidentally stumbled on the correct medicine, must have fatal consequences in the vast majority of cases; and even more so, a complete lack of knowledge has led to the production of a group of superstitious practices. ( $K V$ 1849:83.)

Many sources wrote in a denigrating tone about the magical practices of the dukun. J.A. van Dissel (1869:375), the municipal physician in Semarang, spoke about 'all sorts of superstitious nonsense', and P.J. Veth (1875:487), professor and authority in the field of the colonies (although he had never been there), referred to 'humbug'. Bleeker (1844a:4745 , note 1) also wrote of superstition, but put this into perspective: 'Incidentally, even in our enlightened Holland, superstition is not less in some places'. We hear the same qualification from Boorsma (1913:4): 
The dukun's explanation of causes of disease often sounds to us most eccentric until we remember that in Europe one can find entirely analogous concepts among less developed people, and that one does not have to go that far into the past to find similar concepts dominating our own medicinal practice.

The Europeans thus had no high opinion of the dukun, but there were exceptions. The physician Waitz (1829:40) had viewed the dukun's method with his own eyes, while many other source writers apparently obtained their information secondhand. He recorded that a dukun first tried to diagnose one or two of the most important of the patient's symptoms, then as soon as he knew the name of the disease, he quickly applied all of the medicines from his collection (Waitz 1829:1-2). Although Waitz had the usual criticisms about the dukun's expertise, he did take them seriously: he translated dukun as 'doctor' and described their method in careful detail without calling them witchdoctors. He did not consider the magical aspect of their practice in his book. The physician Greiner (1875:180-1), who reported about an indigenous surgeon in his memoirs, was also an exception. He talked about his 'Javanese colleague' and the 'Javanese doctor'. Greiner stated that the Javanese make great use of massage of nerves, tendons and vessels: 'It is unfortunate that we practise that treatment method so little. The results are highly surprising in some cases.' The Javanese were helpless only when it came to treating eye diseases; in that case they resorted to European medicines, namely a solution of lapis infernalis. ${ }^{35}$ The dukun were very familiar with diarrhoea and dysentery, commonly occurring diseases in the East Indies. They treated them successfully with tannin-containing medicines, even for European patients (Greiner 1875:183). This passage sounded so positive that it only became clear with the words 'half-naked colleague' that Greiner was referring to a dukun and not a dokter djawa, a Javanese with Western medical training.

\section{DUKUN BAYI}

The dukun bayi, a dukun specialised in childbirth, was part of a separate medical market, midwifery specialists, who were almost exclusively

\footnotetext{
35 Greiner 1875:182. Lapis infernalis is an infernal stone, stylus of silver nitrate, used as a caustic agent, for example to cauterise a strongly granulating wound or burn away warts.
} 
women. ${ }^{36}$ It was a market that could count on great interest from the Europeans. The historical sources on this are more numerous and also more emotional in tone than those on other dukun: 'There is no other subject about which so much has been written, with so many case reports and horror stories as that of obstetrics'. ${ }^{37}$ An illustrative example in this connection was given by health officer J.J. Lindgreen:

The population is largely and sufficiently supplied with dukun for accompanying childbirth, which subjects I do not count higher than servants, as their knowledge does not extend any further than tying off the umbilical cord and forced removal; I would even go so far as to say pulling out the afterbirth; however, whenever even a slight complication occurs, then good advice is dear, doors, windows and cupboards must be opened, the house filled with incense, incantations and magical formulas initiated, but practical help is absent. ${ }^{38}$

Negative reports about the dukun bayi can be found from the hand of the physician John Crawfurd (1823:326-7, 332), resident of Yogyakarta during the British administration. He considered their treatment of women in labour improper; it definitely did not amount to much, given that nature did not make it difficult. There really was little to do, he felt, because all births were easy. He ascribed this to the warm climate. This prejudiced notion was shared by many sources, ${ }^{39}$ sometimes on the basis of pelvic measurements (Kleiweg de Zwaan 1910:76-7). Almost all authors assumed that dukun bayi did not conduct any internal examinations. ${ }^{40}$ Many sources reported their ability to turn a fetus lying in an undesirable position in the womb. Some authors, such as the health officer F. Epp (1845:319) and the missionary J. Kreemer (1882:590), did not believe this, while others, such as the gynaecologist C.H. Stratz (1897:46), expressed their admiration of it:

\footnotetext{
$3^{6}$ Verdoorn (1941:40) found on West Java one male dukun among a hundred female bayi; he acted like a woman.

37 Peverelli 1947:27. Kiewiet de Jonge (1911:286) said something similar: 'He [F. Epp in an 1845 article about midwifery among natives] told a few stories which were as horrible as the worst that has been brought to light in the past few years'.

$3^{8} \quad$ AV 1849 Banyuwangi residence, Archief Schoute Banjoewangi.

$39 \quad$ Epp 1845:317; Muller 1846-47:275; Veth 1875:485.

4० $\quad$ Epp 1845:319; J. Kreemer 1882; Greiner 1875:183; Stratz 1897:31; Mayer 1894:27.
} 
The ability to bend and stretch the fingertips as they choose in all directions, the extraordinary flexibility of all parts of the hand and a finely developed sense of touch, supported by great strength and tenacity, allows them to make the most detailed diagnosis and exercise the greatest diversity of skill.

Stratz (1897:36) had seen for himself a couple of times that a dukun had changed a transverse presentation into a cephalic presentation just through external manipulations, once even after the waters had broken, although without the amniotic fluid the space in which to turn the fetus had shrunk. Epp and Kreemer's disbelief is not shared by modern-day gynaecologists because version of the fetus is still done in the womb. Epp considered the dukun bayi as someone with proper insights, but also superstitious foolishness, such as claiming that they could already establish the pregnancy between 8 and 14 days after conception. Telltale signs include blue rings around the eyes, widening of the hips and the milk ducts becoming visible. ${ }^{41}$ Modern-day gynaecologists do not believe it is possible to verify a pregnancy at such an early stage. ${ }^{42}$ The opinions of the missionary Kreemer (1882:591) about the dukun bayi are noticeably detailed and pronounced: 'During childbirth the greatest superstition is combined with the worst ignorance, and if the nature of the matter were not so serious and delicate, one would probably laugh about it'. Some obstetric knowledge was included in his training as a missionary, but whether that justifies the strong judgements he held is doubtful.

A dukun bayi was also tasked with contraception and promoting and reducing fertility. Health officer G.H.G. Harloff (1853:381) described in detail how a dukun bayi could induce an abortion with herbs. Kreemer Jr. (1915:83) inventoried the various abortion methods. Van der Burg (1882:69) reported about dukun who ensured that young girls would not have babies: 'The dukun apparently have the ability through external manipulation to bring about a change in position of the uterus, by bending backwards and forwards, which reduces the chance of becoming pregnant!' If the woman wanted to conceive, the uterus could later be returned at her request to its original position. Van der Burg described in

$4^{1} \quad$ Epp 1845:318. Van der Burg (1882:70) wrote exactly the same as if it were his own observation. This type of data seems often to have been gathered from other writers.

$4^{2} \quad$ Concerning the earliest date at which pregnancy can be determined, L.W. Peters, gynaecologist (interview May 2005), stated that the current method (urine test) can often not verify pregnancy at such an early stage as the dukun claimed. Determination 14 days after conception is logical because the menstrual period stops. 
detail the pain that these patients felt during the procedure, which he had asked them about. Van der Burg appeared to believe, like most Dutch doctors of that time, that this treatment reduced fertility. The gynaecologist Stratz (1897:30, 43-6) also took the dukun's techniques seriously, but when he researched the long-term effects, the results were disappointing. Currently, gynaecologists believe that the position of the uterus does not influence the chance of conceiving. ${ }^{43}$ Eurasian women also consulted a dukun when they were childless, sometimes without the knowledge of their husbands, which led to the following lament from one man:

\begin{abstract}
A dukun was consulted, completely unknown to me, about this important affair, and innumerable conferences were held with that person, whose entire medical knowledge appeared to consist of the fact that she was older, uglier and dumber than any other Javanese woman. Artifices had to be tried, at least one night when I went to bed, I was overcome with a stifling scent of herbs. (Daum 1962:118)
\end{abstract}

With so many negative judgements about the dukun bayi, sometimes even from relatively inexperienced laypeople such as a missionary, the positive ones stand out all the more. The physician Greiner (1875:183), for example, felt that they were not all ignorant of obstetrics. They could conduct a satisfactory external examination, but if they encountered a complication, they resorted to amulets, and the woman in labour was practically tortured. The most striking one is the positive opinion of the gynaecologist Stratz (1897:27-30), on whom the dukun bayi had made a favourable impression. He pointed out the wealth of medicines they had at hand and their extensive practical experience and massage techniques: 'I readily admit that in this respect I have learned a lot from these brown female colleagues'. This compliment is all the more surprising because Stratz (1897:31) also reported about a birth he attended at which two $d u^{-}$ kun 'stepped with their feet on the bare belly of the woman in labour and pushed the baby out'. Few other gynaecologists share Stratz's positive attitude about massage. ${ }^{44}$ The modern gynaecologist A. Haspels ascribes the extremely high number of uterus ruptures (one for every 36 births in Banyumas) to the external massage by dukun bayi (Stein 2007:61, note 6).

\footnotetext{
43 'Retroversio uteri is not a cause of infertility.' Lammes 1997:200.

44 Verdoorn $(1941: 183,195,198-9)$ reported several times about the negative consequences of a massage by a dukun.
} 
There were also other people who offered their services around 1850 on the medical market of Java and Madura, sometimes literally. Usually, the dukun prescribed which herbs the sufferer should take. He obtained them from his own garden or from the market and prepared them (Koentjaraningrat 1979:43). The tukang rëmpa-rëmpa, ${ }^{45}$ a type of herbalist, not only sold medicines but gave instructions for their use. ${ }^{46}$ They often bought their herbs from Chinese wholesalers or from the tukang akar-akar. The latter searched for herbs in the forest and sold them, mostly to a tukang rempa-rempa, but sometimes they sold them themselves on the market (Vorderman 1886:26). Other people also tried to offload medicines there: they were called tukang jual obat (medicine seller) or tukang jamu-jamu (jamu were remedies to keep the body healthy, or occasionally medicines). The tukang jamu-jamu were women who sold medicines, either in raw or prepared form, and occasionally offered consults. ${ }^{47}$ Many of these mixtures were meant to prevent disease.

The European apothecary W.G. Boorsma (1913:28) described one market stall as follows:

Everything is piled up and mixed up, and one does not understand how the saleswoman finds her way. Despite this, she is generally well informed about her supplies and about the virtues they presumably embody, which is apparent from the well-intentioned advice which she continuously offers her customers together with her leaves and herbs.

There were also women who would go door to door with baskets of the most common medicines, ready for use. ${ }^{48}$ Many sold not only medicines, but also themselves (Koentjaraningrat 1979:44). Particular specialists were the tukang ampoh, ones selling the edible red clay, ampoh, primarily to pregnant women who thought that the fetus liked it (Kleiweg de Zwaan 1910:126-7). The entire group of herbal sellers was customer-oriented:

45 Rèmpa-rempa were spices, herbs; the difference between a tukang and a dukun is that the former does not and the latter does have magical powers (Jordaan 1985:162-3, 194). In Central and East Java they were called tukang cerakin (Boorsma 1913:5).

$4^{6} \quad$ According to Boorsma (1913:5) most of them were women, not necessarily Chinese.

47 Greiner 1875:186; Vorderman 1886:26. According to Vorderman (1886) and Van Hien (1924:16) they also called themselves tukang rempa-rèmpa.

$4^{8} \quad$ According to Vorderman (1886:27), they would be primarily soldiers' wives. 


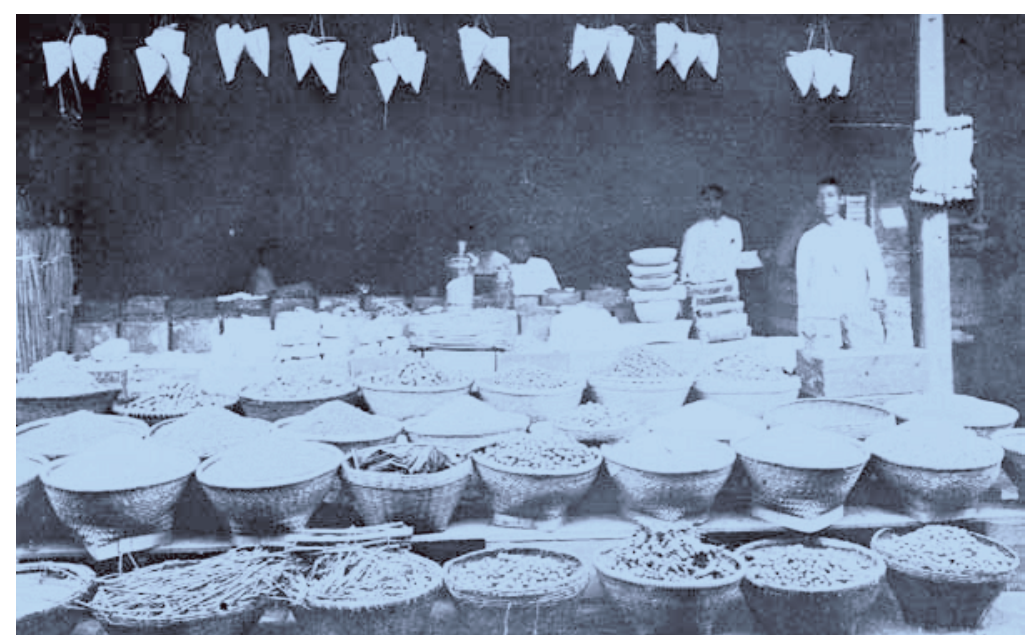

Wholesaler in medicines in a Chinese district in Jakarta (photo collection KIT 10006705)

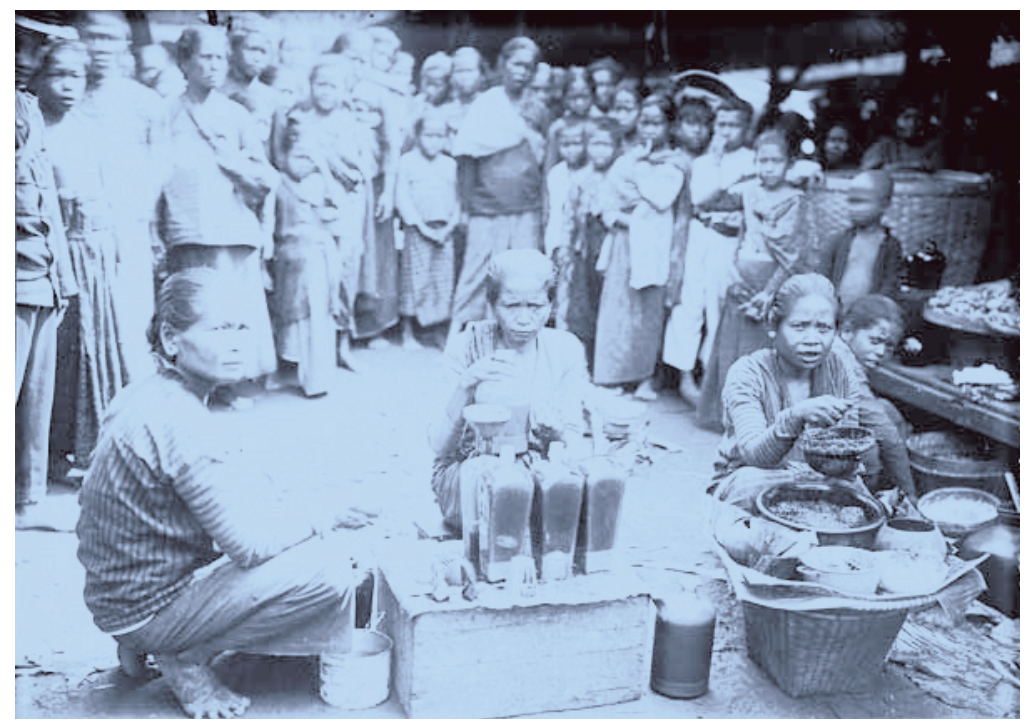

Women in the market. Photo taken by the well-known photographer Cephas of the market in Yogyakarta about 1910. On the right, jamu bagolan is being prepared, a mixture popular with women and children. The woman in the middle has a popular drink, jaтu parěm, in her bottles. (photo collection KIT 60027026) 
sufferers could decide for themselves which medicines to buy and how much of them.

\section{CHINESE HEALERS}

The Chinese formed a rather closed group with their own leaders; their relative isolation resulted from being barred from certain professions. They were not allowed to rent land (Bosma and Raben 2008:107). They had their own medical facilities: healers (sinse), ${ }^{49}$ pharmacies, ${ }^{50}$ and hospitals, including ones in Jakarta and Semarang. There were at least 10 Chinese pharmacies in Jakarta and certainly one in Kedu. ${ }^{51}$ They imported their medicines, especially herbs, from China, the Indian subcontinent and Arabia. ${ }^{52}$ They also bought them from the tukang akar-akar. In 1860 there were 30 Chinese apothecaries in the town of Jakarta; ${ }^{53}$ and in 1885, 67 Chinese healers in the residency of Jakarta; the large majority would have lived in the capital, Jakarta. ${ }^{54}$ In 1865 , the government appointed a Chinese vaccinator in Jakarta to inoculate the Chinese population. ${ }^{55}$

According to Bleeker (1844b:264), the Chinese healers in Jakarta did not have the anatomical knowledge available in China. The foundation and guideline for their treatment consisted of feeling the pulse. Bleeker did not have anything positive to say about this: 'Truly a pathology from the Middle Ages!' The health officer J.G.X. Broekmeyer (1856:39) was equally negative about their therapeutic knowledge. A description by Van der Burg (1882:82) reveals that they practised acupuncture. European physicians did approve of the Chinese remedies as they did of the native ones. Broekmeyer (1856:39) confirmed, 'At very least, it

49 Currently known as sinshe or singse (xiangsheng) (Rizal 2004:27).

$5^{\circ} \quad$ According to Boorsma (1913:49) no competence criteria were imposed on the right to exercise medicine or to prepare remedies. Medicine and pharmacy were not separate in practice; students were trained in the apothecary.

$5^{1} \quad$ Vorderman 1890:7; Archief Schoute Kedoe 1852. Boorsma (1913:45) marvelled at the large number of apothecaries in a Chinese neighbourhood. According to Geneeskundigen (Inlandsche) (1917:768) there were exclusively Chinese pharmacies in Jakarta, but this is not correct as there were also European pharmacies.

$5^{2} \quad$ Boorsma $(1913: 47-8,51)$ ascertained that the medicines from China looked clean and attractive; recently, they had encountered competition from prepared medicines from Japan.

53 Abeyasekere 1987:200, 209 note 52.

$54 \quad K V$ 1887:appendix A; Abeyasekere (1987:189-210) stated 89 on the basis of the same $K V$.

55 Archief Schoute Batavia 1865. 
cannot be denied that the Chinese healers have knowledge about the effect of different medicines'. Bleeker (1844b:269, 283) saw similarities between the Chinese and the European materia medica; this also applied to the arrangement of pharmacies and the preparation of simple medicines. Therefore, he suspected that both materia medica originated from the Indian subcontinent. It was probably difficult to distinguish the native and Chinese medicinal herbs, as the Chinese had been living there for generations and were so familiar with the indigenous herbs that they considered them Chinese. The transmigration doctrine was part of their medicine - just as it was with the natives (Vorderman 1890:5-6).

\section{CHINESE MEDICINES}

Some sinse were known to have access to special medicines and were sometimes prepared to sell the formula for a lot of money. E.F. Meijer (1856:269-72), health officer in Riouw, told the story of a Chinese man who arrived from Singapore in 1855 and claimed to be able to extract teeth painlessly, even molars. Many inhabitants visited him, and several praised him. Meijer summoned the man and purchased his secret. It involved two powders: one a painkiller and one to loosen the teeth, making them easier to pull. Meijer used the first powder with great success; he felt the second one only worked moderately well.

In his report about the second semester of 1848, A. Schultz, health officer in Sambas (West Kalimantan), stated that a Chinese ksing-ksang had a remedy for leprosy and/or elephantiasis. The head of the Medical Service asked him to send the formula and the medicines directly to Jakarta, but the man asked an exorbitant sum of money for this. Ultimately, in 1855 the deputy resident succeeded in purchasing these medicines for $f 1376.90$ (current value $€ 10,310$ ), after which the man in question disappeared without a trace. Another Chinese man, who also knew about this product, was summoned to Sambas to treat three Chinese patients with it in an accommodation near the clinic under Schultz's supervision. The formula - which consisted of several potions, salves and pills - was prepared by a Chinese apothecary. During the trial, one patient died, and of the two survivors only one appeared to be a bit better. After this course of treatment lasting four months, the Chinese dukun wanted to carry out further therapy that would also 
last several months. ${ }^{56}$ 'However, as the main course had had so little result and both Chinese (the healer and the supplier of the medicines) wanted to extend it, partly from embarrassment about the poor result, partly from greed, it was decided, to avoid further useless expense, the reasonable option was not to continue' (Wassink 1859c:363). Head of the Medical Service Wassink (1859c:363) commented that the effect of the medicines was dubious and that the same result could have been achieved with 'an energetic application of known substances from our own materia medica'. He went on to make the following remark: 'Through the generous and caring principles of the government, which does not spare any costs that serve the interests of humanity and science, we were able to test another of the secret therapies so often applied in the East Indies' (Wassink 1859c:364). The Chinese medical practitioners surpass the most infamous European quacks in cunning and impudence: '[T]hey understand everything, except the art of healing patients' (Wassink 1859c:365). Wassink (1859c:366) ended with the words: 'We refuse to comment'. Given what was stated before, this last remark seems to be far from the truth. Apparently, the Medical Service wanted to have use of the secret formula. Even the deputy resident was involved in its acquisition, and a large sum was paid for it. The trial was carefully arranged: everything was described in detail, including the 20 components of the formula. The Medical Service was clearly looking for new possibilities and thought they could learn from the Chinese. Neither expense nor effort was spared. The disappointment was naturally great when the formula appeared to be worthless.

\section{EUROPEAN MEDICAL PERSONNEL}

\section{PHYSICIANS}

In the East Indies there was just one medical service charged with caring for both soldiers and civilians. The health officers had to care for civilians in the neighbourhood of their garrisons in their spare time. If there was no health officer posted to a particular location, a private physician could be requested by the government to fill in for the Civil Medical Service

\footnotetext{
$5^{6} \quad$ The first Chinese doctor was called ksing-ksang and his colleague was dukun. Probably, this referred
} to sinse in both cases. 
and also act as superintendent of the vaccinations. He was then named a civil physician and received for this a monthly stipend of 50-75 guilders. ${ }^{57}$ Only the three large towns on Java (Jakarta, Semarang, Surabaya) had their own municipal physicians. It is evident that the Civil Medical Service was clearly subordinate to the Military Medical Service. In addition, there were some private physicians, often health officers who had left the military service. ${ }^{58}$

We have the most information about European physicians. It is correct to talk about European physicians in this case because in the nineteenth century many Europeans, especially Germans such as Waitz and Stratz, worked as health officers in the East Indies Army. ${ }^{59}$ There were always vacancies: in 1848 there were 20 openings and in 1868 up to 40, a quarter of the complement. ${ }^{60}$ Serving in the tropics was not very popular because of the low salary, mandatory 15 -year posting, the poor chances for promotion, the low pension and the high mortality (De Knecht-van Eekelen 1988:95, 130). Half of the health officers who started their posting in the period 1820-1860 in the Dutch East Indies died within five years (Kerkhoff 1989:11). With so many vacancies it is striking that the government regularly released health officers for non-medical tasks, such as Jurriaan Münnich, who photographed antiquities in Central Java in 1840 (Van den Berg and Wachlin 2005:227), Franz Wilhelm Junghuhn, who could devote almost his entire career in the East Indies to the study of natural phenomena, and Eugène Dubois, who was able to investigate the missing link between man and ape.

The health officers were charged with the care of civilians in the region of their posting - as far as their military service permitted it. Most of them did not understand the local languages, not even Malay. ${ }^{61}$ Indigenous languages were not included in their training, in contrast to that for the civil servants. This implies that the government expected that they would only treat European civilians. And. in practice, the population rarely asked for their help. The health officer in Banyumas treated

\footnotetext{
57 'De geneeskundige dienst in Nederlandsch Indië', GTNI 1(1853):80.

$5^{8} \quad$ Geneeskundige Dienst 1917:761. Van der Burg 1882:342 left the military service after 8 years as health officer and established himself as a private physician in Jakarta.

59 Actually, it is incorrect to talk about Germans before 1870, the year of German unification; for convenience's sake the label is also used for the period before 1870 .

6o Respectively: Letter from Rochussen to Baud 28-2-1846 no. (5) 44, Baud 1983b:92-3 and De Knecht-van Eekelen 1992:409.

61 Letter from the commander of the East Indian Army, F.D. Cochius, to the GG 29-11-1847, in: NA, Koloniën, 1814-49, 2.10.01, inv.nr 1849, Vb. 7-4-1848 N 2/205.
} 
only 17 Javanese in the entire year of 1846 (Algemeen Overzigt 1848:206). The only time many natives did require Western medical help was when an epidemic struck. During a fever epidemic in Banten in 1861, the resident praised the two health officers for their generous and selfless efforts as they did not ask monetary payment from the population. ${ }^{62}$ This last compliment was unjustified because caring for civilians was part of their job.

There were health officers who loathed treating civilians, especially natives, or perhaps they were just lazy. The civil servant A. Pruys van der Hoeven gave an example of this in his autobiography, Veertig jaren Indische dienst [Forty years of service in the East Indies, 1894]. In his district, the retiring physician had always helped his patients immediately. His successor used to regularly turn natives away with, 'Come back tomorrow at 10 o'clock', assuming that most of them would not return. The population complained about the behaviour of this new doctor. One particular day, Dengoean, a prominent native, asked Pruys van der Hoeven (1894:135-6),

\footnotetext{
'Could you please tell me whether the doctor that is here now had as good a training as the last one?'

'Why do you ask?'

'Because', answered Dengoean, 'the former doctor, when a patient visited him, always knew immediately what he needed to do, while this one always has to think about it until 10 o'clock the next day.'
}

The natives did not like surgery. If they allowed themselves to be operated on by a European physician, it sometimes led to an uproar. The resident of Yogyakarta recorded in his report for 1848:

One operation deserves to be mentioned, as it caused quite a sensation regarding European medicine among the population. An indigenous priest had had a tumour on his throat for 22 years, which had gradually reached a weight of $26^{1 / 2} \mathrm{lb}$ and by impeding breathing and swallowing was threatening the life of the sufferer and making him miserable. It was removed by health officer 2nd class F. Cornet, the local physician, with a successful result. ${ }^{63}$

62 AV 1861 of the Resident of Banten, Archief Schoute Bantam.

${ }_{63}$ Archief Schoute Djokjakarta. 
Most Europeans lived in the three large towns on Java, where the municipal physicians were located. The latter were required to assist for free European civil servants who earned a monthly salary under 150 guilders and poor people in all civilian government institutions such as town clinics and charities (Ind. Stb. 1825 no. 9). In addition, like the health officers, they were permitted to run a private practice as long as their official obligations did not suffer as a result ( $K V$ 1849:92).

The residents often complained in their reports that the health officers hardly ever saw the civilian population: 'Officially, the health officer in Bankulen is the vaccine superintendent, but he never leaves his garrison, and even then, one man can hardly supervise such a vast region' (Pruys van der Hoeven 1864:50). Various residents tried to convince a private physician to establish himself in their district; sometimes the inhabitants even collected a fund for this. But even when they succeeded in attracting someone, he often left after a short time because of the poor payment (Schoute 1936:127). This happened in the Jepara residency in 1852 where the Europeans were so healthy that the private physician was not earning enough in fees. When they did get sick, they didn't need him because they had in the meantime learned how to treat themselves with the indigenous medicines.

The group of European physicians formed a corps, a rather small group of doctors that met each other quite often due to the frequent transfers. A physician gained the right to paid leave in Europe only after 15 years (Selberg 1841:442). The common preparatory training, usually conducted at the Rijkskweekschool voor Militaire Geneeskundigen in Utrecht, contributed to the spirit of a corps. Former health officers often established themselves as private physicians and remained members of the corps. The heads of the Medical Service undertook all sorts of activities to strengthen the spirit and the quality of the corps, such as setting up a medical reading club in Jakarta in 1828 and the Natuuren Geneeskundig Archief voor Neêrland's Indië (Archive for Natural Science and Medicine in the Dutch East Indies) in 1844 (Schoute 1936:130, 143). A medical library was also created for the health officers ${ }^{64}$ On the initiative of $\mathrm{W}$. Bosch, the weekly meetings in the military hospital in Jakarta (the so-called Conversatorium) gained a more formal character: in 1851 the Vereeniging tot Bevordering der Geneeskundige

${ }_{4} \quad$ In 1847 a heated dispute arose about the cost of purchasing new books between W. Bosch and his boss, lieutenant-general Cochius (Baud 1983c:186-7, note 6). 
Wetenschappen in Nederlandsch-Indië was established. ${ }^{65}$ It soon began to publish its own journal, the Geneeskundig Tijdschrift voor Nederlandsch-Indië. The first number appeared even earlier than that of the Nederlandsch Tijdschrift voor Geneeskunde, which was published in January 1857.66

\section{APOTHECARIES}

There were 3 municipal, about 25 military and 9 private apothecaries on Java. ${ }^{67}$ Military apothecaries often sought a civilian position - just like military doctors - as it paid better. European apothecaries were bound by various government stipulations: they had to work according to the Pharmacopoea Belgica and keep at least a year's supply of all preparations listed in it. ${ }^{68}$ In addition, they had to have access to a chemistry laboratory where all the formulas in the Pharmacopoea Belgica could be prepared in case of calamity ( $K V$ 1849:93). This stipulation applied only to European apothecaries and medicines, not to the preparation and supply of medicines by Natives and Foreign Orientals ( $K V$ 1849:83). This is strange because many European doctors used indigenous medicines.

\section{MIDWIVES}

In the three large towns on Java, there were in total five municipal midwives. In addition, there were private midwives, who were sometimes retired municipal midwives. ${ }^{69}$ European midwives were obliged to assist poor pregnant women for free and to train interested European and native women to become midwives. For each woman who passed the exam, they received a bonus of 50 guilders. These stipulations from 1817 were still in force in 1899 (De Freytag 1899:45-6). Outside the large towns, the dukun bayi generally managed the deliveries of European women; only when there were complications was the help of a physician sometimes called in.

\footnotetext{
${ }_{65}$ Schoute (1936:247-8) ascribed this to Bosch; Borgers (1941:127) disputed it.

66 The date of the first issue varies from 1851 to 1853; the journal had a subsidy from the government, first $f 900$, later raised to a maximum of $f 2000$ annually (Borgers 1941:128-9).

${ }_{67}$ Almanak en naamregister 1850 listed 22 military apothecaries; $K V$ 1849:11 listed 29; both sources named 3 municipal apothecaries; $K V$ 1849:95 listed 9 private ones.

68 The Pharmacopoea Neerlandica introduced in the Netherlands in 1849 was first declared generally applicable to the East Indies in 1862 (Schoute 1936:277).

$69 \quad$ Veranderingen geneeskundig personeel 1853:161.
} 
The European midwives enjoy great respect in the European society in general, and in the Chinese to some extent; they have such a great influence on the ladies that their advice is almost always heeded above that of the physicians; they dare to carry out almost every assisted delivery method; administer medicines, etc.; they look down on the physicians with some disdain, who are called to assist in deliveries; want to instruct them in what they must do, and rely on their own extensive experience instead of scientific knowledge. (Van der Burg 1882:343.)

Apparently, Van der Burg was incensed that pregnant European women preferred to listen to midwives with experience rather than physicians with scientific knowledge. With repugnance, he ascertained that midwives applied instruments during deliveries, a method legally reserved for physicians (Ind. Stb. 1882 no. 97 art. 53), and he considered it unacceptable that the position of the midwives was so unassailable that this transgression went unpunished.

\section{LAYPEOPLE}

There were formal sanctions against unqualified people practising Western medicine, ${ }^{70}$ but this was rendered inoperative in practice as the competency criteria did not apply to Natives nor to Europeans who assisted in the absence of a physician (Ind. Stb. 1853 no. 99). The latter situation occurred on a large scale. Basic medical services were part of the official tasks of controleurs, Dutch officials responsible for the administration of a number of districts and thus laypeople in the medical field. They had access to a medicine chest with instructions for its use (K.W. van Gorkom 1878:127). Nothing made a controleur more popular than supplying medicines; it was said to be even more important than knowledge of the local language or capacities. ${ }^{71} 72$ 


\begin{tabular}{|l|l|}
\hline Garegiver & number of \\
\hline Dukun & $11,421(1884)$ \\
\hline Chinese healer, sinse & $268(1884)$ \\
\hline European health officer from CMS & 19 \\
\hline European physician (municipal, private, civil) & $5+15+9$ \\
\hline European apothecary (municipal, private) & $3+9$ \\
\hline European midwife (municipal, private) & $4+?$ \\
\hline
\end{tabular}

Table 2.1. Number of medical caregivers from CMS on Java around $1850 .^{73}$

\section{HOSPITALS}

Medical goods and services were provided not just by individuals, but also by institutions like apothecaries and hospitals. The Military Medical Service and the Civil Medical Service were actually one organisation, as were the infirmaries. Civilians were also treated in the military hospitals ( $K V$ 1849:93). They were classified into large hospitals, garrison hospitals and infirmaries ( $K V$ 1849:15). In 1867 there were three large military hospitals on Java (in Jakarta, Semarang, Surabaya), around 200 garrison hospitals and 43 infirmaries. ${ }^{74}$ Throughout the East Indies the government had introduced four classes of patients in the hospitals, based on their rank in the military or civil administration or status in society (Weitzel 1860:33-4). In the large military hospital in Jakarta, Natives and Europeans were treated separately, as were non-commissioned officers and soldiers. Officers had their own room (Weitzel 1860:33). In addition, there were civilian medical institutions such as the municipal clinics (stadsverband) in the three large towns on Java, where convicts and poor natives were treated and nursed free of charge. The municipal clinic in Jakarta treated 3000-4000 patients each year (Abeyasekere 1987:199). Outside the three large towns, sick prisoners remained in prison, and sick convicts in the barracks ( $K V$ 1849:81). In 1856 the government supported ten native hospitals on Java and Madura and one on Ambon (Wassink

73 KV 1849:10-1, 95 Almanak Nederlandsch-Indië 1851:219-20.

74 Schoute 1937:159; De Knecht-van Eekelen (1992:410) gives the same figures as Schoute, with the understanding that De Knecht incorrectly assumed that the number of garrison hospitals $3^{\text {rd }}$ class cited by Schoute was the total number of garrison hospitals. Ludeking (1871:53-6) gives very different figures: 4 large military hospitals, 33 garrison hospitals and 46 infirmaries. 


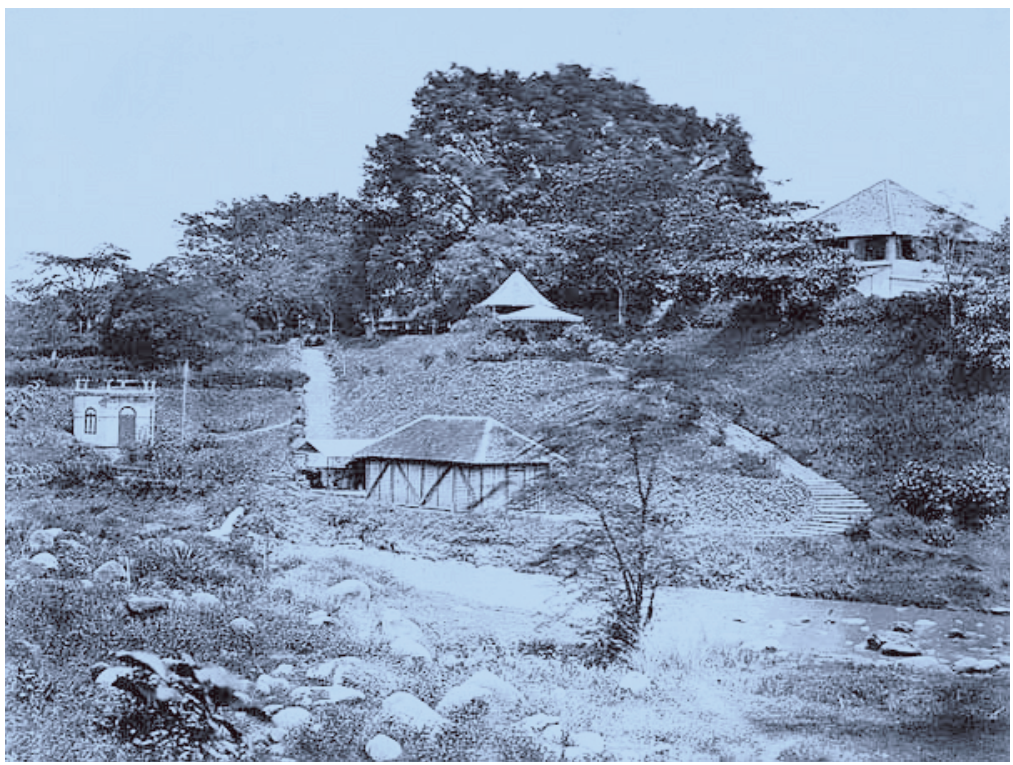

A hospital in Malang around 1880 (photo collection KITLV 82774)

1859a:236), mostly in buildings made of bamboo (Schoute 1936:302). The nursing was in the hands of untrained orderlies (Sciortino 1996:29). In addition, there were institutions for the poor, beggars and lepers. The indigenous population had a great aversion to hospital admission (Schoute 1936:128), which was understandable given the quality of care and the other occupants. They were also convinced that people in a hospital were always operated on. At the beginning of the twentieth century, a servant who had been bitten by a poisonous snake would rather have died than go to the municipal clinic (Kloppenburg-Versteegh 1940:91). Europeans were also adverse to a stay in a hospital. Long before he was fully recovered, the health officer Bosch, the later Head of the Medical Service, left the military hospital in Jakarta in 1818 for fear of otherwise not getting out alive (Borgers 1941:14).

Sometimes a special hospital was established for prostitutes infected with syphilis, including ones in Kudus (Semarang), Madiun and Bogor in 1858 and in Cianjur (Priangan) in 1854. ${ }^{75}$ The building in Cianjur was

75 Archief Schoute Preanger 1853; Archief Schoute Madioen 1863; Archief Schoute Buitenzorg 1858. 
financed by the indigenous population, which can explain the relatively high number of admissions. ${ }^{76}$ In the first quarter after the opening, 207 people were treated, ${ }^{77}$ while in an entire year (1860) in the hospital in Kudus 212 women were admitted and in Bogor $120 .{ }^{78}$ In his annual report, the resident of Priangan noted that in Cianjur several people had come voluntarily to the hospital 'to be healed of their Venus disease'. Infected men were also treated. ${ }^{79}$ The percentage of women who were cured was high, if we examine the figures from Bogor: 85 of 120 in 1860, and a year later 273 of 303.80

In towns with many Chinese inhabitants, like Jakarta and Semarang, there were separate Chinese hospitals. In Jakarta the hospital aimed to treat 200 patients at a time: 100 'normal' sick Chinese and 100 Chinese and Native mentally ill patients, amounting to 5000-6000 patients a year (Abeyasekere 1987:199). There was a separate section for mentally ill patients, consisting of 41 small rooms around a square courtyard. The institution was under the supervision of the first municipal physician (i.e., not a Chinese healer), who was supported by 24 servants (Bauer and Smit 1868:33-4). Starting in 1827 it was granted a subsidy by the government. ${ }^{81}$ In 1845 in Patjerongan, about $5 \mathrm{~km}$ from Semarang, a Chinese hospital was built, and just as in Jakarta about 40 mentally ill patients were cared for along with sick Chinese, separated into a men's and a women's ward. In each ward there were three rooms to isolate serious cases (Bauer and Smit 1868:35).

The archipelago with its many volcanoes contained numerous therapeutic springs; the Encyclopaedie van Nederlandsch-Indië devoted almost three pages to them (Bronnen 1917:412-5). The spring's water could be bathed in (balneotherapy) or drunk. In the immediate surroundings of some springs, simple accommodations had been built, for which only the rich paid a small fee (Bronnen 1917:412). The accommodation was generally built only after the therapeutic properties of the spring had been confirmed; European and native civil servants and Chinese mer-

\footnotetext{
$7^{6}$ GB 28-5-1854 no. 17, AV 1854, Archief Schoute Preanger.

77 AV 1854, Archief Schoute Preanger.

$7^{8} \quad$ Archief Schoute Japara; Archief Schoute Buitenzorg.

79 Archief Schoute Preanger 1853.

8o Archief Schoute Buitenzorg.

81 Abeyasekere 1987:199. For a summary of the various money flows in the Chinese hospitals in the three major towns, KV 1849:144.
} 


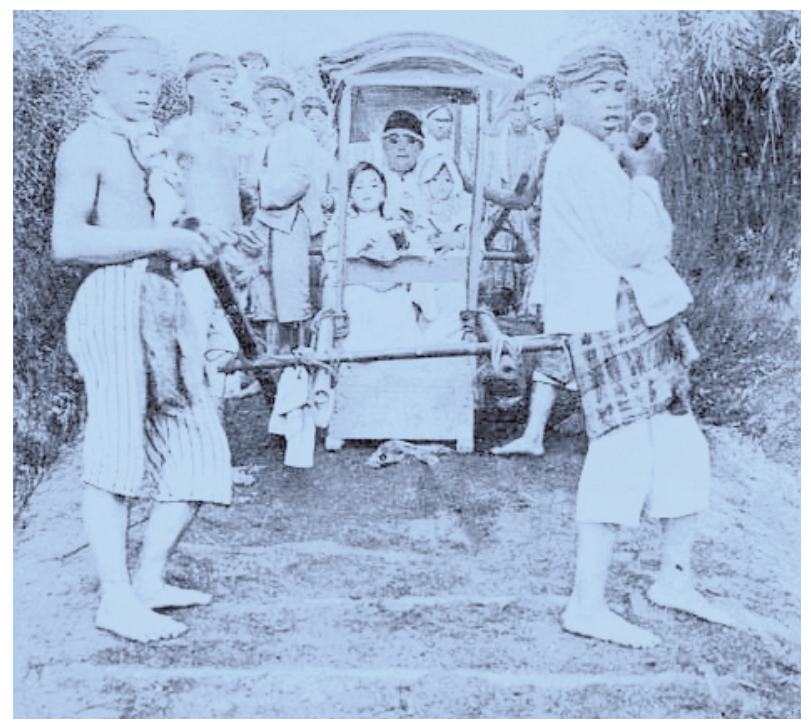

Journey by tandu, sedan chair, to the 'fresh air sanatorium' Tengger (East Java). This was how Johannes Hofhout was transported from Jakarta to Cipanas. (photo collection KITLV 30962)

chants contributed financially to its construction. Germans were already familiar with therapeutic springs from home. The presence of many Germans in the East Indies army could explain why the Medical Service constructed its own bathing facility at the hot springs in Pelantungan, 60 $\mathrm{km}$ from Semarang. This spa was later exploited by a private physician, C.C.W. Mandt, who received a subsidy from the government for years in exchange for admitting a number of civil servants. ${ }^{82} \mathrm{~A}$ similar arrangement was made with the physician Ploem for Sindanglaya at Cipanas (Priangan) (Gramberg 1868:19). In these spas Europeans could unwind, just like in a few sanitoria in the mountains (Unarang in the residency of Semarang; Malang in the residency of Pasuruan; Kampung Makassar in the residency of Jakarta). ${ }^{83}$ The journey to a sanitorium was arduous, long and risky for a patient because of tigers or robbers. It took Johannes Hofhout seven days to travel from Jakarta to Cipanas around 1760; there

\footnotetext{
82 Mandt, a former health officer, received a stipend from 1852 until his death in 1862, Archief Schoute Semarang.

$8_{3} \quad$ Schoute 1936:162. According to Den Hertog (1991:60), the auxiliary clinics of the large military hospitals were located in the three major towns and established in 1848, 1853 and 1869, respectively.
} 
were two days of rest on the way, and one patient died. But it was worthwhile because after 16 months he was healed. ${ }^{84}$ If these health resorts did not offer any relief, then the person took sick leave and returned to Europe.

Some hospitals were not funded by the government, especially in Priangan. Instead, the expenses were paid by the zakat, a tax promoted by Islam (one of the five pillars), which was faithfully paid in Priangan. The institutions were meant first of all for nursing syphilitic prostitutes and, as far as the community permitted it, also sick prisoners and other natives. In the syphilis hospital in Cianjur (Priangan), the government paid for the medicines and the remuneration of the dokter djawa. The building, maintenance, running costs and food were paid by the population. Each year a sum of $f 2000$ was provided from the zakat, which was primarily collected from rice sales. So as not to burden the population too much, renovations of the building were spread over a period, such as replacing the atap by roof tiles and laying a wooden floor. ${ }^{85}$ When syphilis wreaked devastation in the residency of Tegal around 1825, the regents had to ensure that the sufferers were not roaming the streets but were housed in the kampong. The regents decided then 'to reserve a small part of their and the incomes of native civil servants and retirees for use to create a separate ward' ${ }^{86}$ A form of communal financing occurred frequently: the costs for the beggars' infirmary in the residency of Yogyakarta were paid by the Europeans, the Chinese and the sultan. ${ }^{87}$ We also saw communal financing by people from different population groups for the springs in Banten. ${ }^{88}$

\begin{tabular}{|l|l|}
\hline Type of institution & Number \\
\hline Large military hospitals & 3 (Jakarta, Semarang, Surabaya) \\
\hline Garrison hospitals & circa 200 \\
\hline Infirmaries & 43 \\
\hline Municipal clinics & 4 (Jakarta, Semarang, Surabaya, Cirebon) \\
\hline Chinese hospitals & 3 (Jakarta, Cirebon, Semarang) \\
\hline
\end{tabular}

$8_{4} \quad$ F. de Haan 1911:appendix XXXIV.

$8_{5}$ AV 1854, Archief Schoute Preanger.

86 Citation from the letter by Vriesman, former resident of Tegal, to the GG 10-11-1859, Archief Schoute Tegal.

${ }_{8} \quad$ AV 1853, 1855, 1861, 1875, Archief Schoute Djokjakarta.

88 Bronnen 1917:412-4. 


\begin{tabular}{|l|l|}
\hline Type of institution & Number \\
\hline Native hospitals & $?$ \\
\hline Springs and spas & circa 40 (at least 6 ) \\
\hline Sanitoria & $?$ \\
\hline
\end{tabular}

Table 2.2. Medical facilities on Java around $1865 .^{89}$

\section{RULES OF THE GAME}

The 'markets with medical goods and services' described above were influenced by the adat and religion as socio-cultural factors and by several aspects of the colonial policy as socio-economic factors. Supply and demand in the medical market were determined by them to a certain extent. That is why they are called the rules of the game here.

\section{ADAT AND RELIGION}

Religions such as animism, Islam and Christianity have principles that act as restrictions governing the medical market. Islam on Java had incorporated many local customs and practices from animism, Hinduism and Buddhism. We see the same with the adat: some taboos are derived from earlier religions, others from Islam, and it is not always clear whether a particular one was derived from Islam or the adat or both. For example, operations and other surgical techniques were considered unlawful on religious grounds and because of the adat (Mayer 1918:5). In animism the soul was a condition of existence. The soul could leave the body through a wound or surgery, which would result immediately in death (Kreemer Jr. 1915:5). C. Snouck Hurgronje, the foremost Dutch scholar of Islam and principal adviser to the colonial government on Islamic and indigenous matters, pointed out that Islam condemned the indiscriminate implementation of changes in the body and forbade them if they resembled mutilation (Kleiweg de Zwaan 1910:231). Muslims believe that they must appear intact before the gates of heaven (Kloppenburg-Versteegh 1940:91). The sources never noted surgery being performed by dukun, not even simple operations like lanc- 
ing of an abscess or extracting a tooth. Kleiweg de Zwaan (1910:203-4) observed personally that the inhabitants of Minangkabau refused both treatments.

According to the Koran, it was forbidden to introduce a foreign substance into the blood, and thus people fought against the cholera vaccination. Resistance was less to the smallpox vaccination because it was administered more on the surface (De Knecht-van Eekelen 1989b:62). Nevertheless, there were also orthodox Muslims who refused to be vaccinated against smallpox. ${ }^{90}$ The Koran forbids the drinking of alcohol and thus of wine, a Western medicine in those days. In a circular the head of the Medical Service pointed this out to the health officers and emphasised strongly that wine should be given only to patients who had no objections. ${ }^{91}$ The government did not want to offend the Muslims and thus incite unnecessary resistance to Western medicine.

The adat determined that the umbilical cord could only be cut after the placenta was delivered because the child and its afterbirth were apparently brothers. They were to be separated only after both of them had been born. ${ }^{92}$ Because the natives attached great significance to this stipulation, they remained faithful to the dukun bayi, who respected this rule. In contrast, the Western-trained physicians and midwives did not want to endanger the life of the mother and child by doing this.

Abortion was forbidden by Christianity. Officially, the European physicians did not perform this procedure. ${ }^{93}$ For the population the situation was different. According to Islam abortion in the first four months of pregnancy was not a sin because Allah only blew the vital life force into the fetus at that point. ${ }^{94}$ Dukun bayi performed abortions for both native and Eurasian women. The health officer Harloff (1853:383) deplored the fact that Javanese women did not consider abortion a crime or sin and underwent the procedure, sometimes even with their husbands' con-

\footnotetext{
$9^{\circ} \quad$ AV 1852 resident of Bagelen, Archief Schoute Bagelen.

$9^{1} \quad$ Circular from the head of the Medical Service 17-12-1858 no. 2313/2046, Ludeking 1871:102-3.

$9^{2} \quad$ Kleiweg de Zwaan 1910:65. Islam apparently has a stipulation here. Penghulu had declared that when the mother dies before the afterbirth is expelled, it was God's will that the child also die. The child remained tied to the dead mother and was buried with her, according to Van Kol 1903:746.

93 Van den Burg (1882: 99) wrote: 'It is a disagreeable business in practice that a physician is so often asked for the means to expel the fetus, a request that naturally is refused as often as it is asked'. His colleague J. Schülein (1905a:27) wrote in 1905 that in 25 years he had only conducted an abortion twice, but that no year passed without receiving numerous requests.

$94 \quad$ Kleiweg de Zwaan 1910:123; Bennett 2005:108; Niehof 2006:175.
} 
sent. He hoped that this would gradually change through the influence of Western civilisation and by administering punishment.

The adat defined the relation between the classes in the indigenous society. This involved different forms of etiquette, rights and obligations. The adat prescribed that people of standing, like a dukun, should be honoured and showered with gifts. Dukun did not formally charge for their services, perhaps because they felt that it was God rather than their actions that healed the patient. ${ }^{95}$ In practice they did receive compensation in the form of money, goods or services, but it is important to note that this compensation was 'voluntary'.

\section{COLONIAL STIPULATIONS}

The government did not involve itself much with the indigenous population nor with their health. As part of indirect administration, this was the task of the regents. ${ }^{96}$ Nevertheless, certain aspects of the colonial policy did exert an influence on the medical market.

\section{CLASSIFICATION IN RACES}

In 1854 the Dutch colonial state divided the population of the archipelago legislatively into two categories: Natives and Europeans. Towards the end of the nineteenth century a third category was added, namely Foreign Orientals, consisting mainly of Chinese residents. Each ethnic group was governed by specific statutes and was expected, to a large extent, to manage its own affairs while also living in distinct neighbourhoods. It has been suggested that there was little interaction between Europeans, Natives and Chinese in the field of health provision and that those who were in need of medical assistance made use of healers who shared the same ethnic background. ${ }^{97}$ There were many exceptions, however, and some healer hopping (Hesselink 2010:117).

95 H.H.B. Saanin DT Tan Pariaman 1983:159 (professor of psychiatry and director of the State Mental Hospital in Bandung) said that in his 35-year practice he had never asked for one cent. Perhaps he meant to say that he did not take the initiative. Probably he was paid, either by the patients, or in the form of a salary from the hospital.

$9^{6} \quad$ 'Reglement op de verpligtingen, titels en rangen der Regenten op het eiland Java', Ind. Stb. 1820 no. 22 art. 9.

97 'In the medical area, there was very little contact with the indigenous population' (De Knecht-van Eekelen 1989b:58). 
The sources emphasised in a variety of ways the great resistance of the indigenous population to Western medicine and its practitioners (Schoute 1936:189, 201). Nevertheless, we do know of cases in which natives allowed themselves to be treated by a European after first consulting a dukun. 'Usually, several well-known remedies had already been tried, or a dukun had already attempted to help' (Van der Burg 1882:65). During delivery, several dukun bayi would generally have already assisted unsuccessfully before a European physician was consulted. Thus, the health officer Lindgreen was only called in after three dukun had given up; he delivered a healthy child. He was disappointed that this 'success' did not lead to his help being requested again - although he had offered it free of charge. ${ }^{98}$ There was less resistance to medicines from Europe, such as quinine, castor oil, santonin biscuits (against intestinal disorders), iodoform, laudanum (opium tincture) and Bleeker's cholera drink, than to European doctors (KV 1852: 68-9).

The indigenous elite formed an exception. The susuhunan of Surakarta had a European personal physician, health officer Harloff. And the civil physician I. Groneman was the personal physician of the sultan of Yogyakarta for a long time. ${ }^{99}$ Harloff (1853:384-5) was consulted for the slightest indisposition, and his instructions concerning diet and medicines were followed faithfully. It is striking that the women at court allowed themselves to be treated by him, even during deliveries (Schoute 1936:184). The resident of Surakarta wrote in his annual report for 1853 that Harloff enjoyed so much trust 'that he was almost the exclusive obstetrician for indigenous women. This example is unique.'100 Also, health officer D. Doyer treated the daughters of the regent of Salatiga for typhus in 1863 (Schoute 1936:345). A special case in this connection was the dukun in the residency of Palembang, who visited health officer J.F. Buning because of a tumour. Through this successful treatment, Buning won his trust and came to learn a lot about his medical knowledge. Buning (1863:215-23) discovered that the diagnosis and treatment methods of the indigenous physician, once divested of the magic, often resembled his own.

Affluent Chinese and Arabs let themselves be treated by a European on occasion (Van der Burg 1882:82). The European missionary doctor

${ }_{98} \quad$ AV 1849 resident of Banjoewangi, Archief Schoute Banjoewangi.

99 Groneman was personal physician from 1869 to 1889, Buddingh' 1989:5, 7.

100 Archief Schoute Soerakarta 1853. 
H. Vortisch van Vloten had a Chinese patient. A sinse had originally dissuaded him from consulting Vortisch because he could kill his patients, then take control of their soul and bring them back to life again. Vortisch suspected that this referred to anaesthesia with chloroform before surgery (Kreemer Jr. 1915:6, note 1). Vorderman (1886:46) had a popular practice among Arabs in Sumenep (Madura) around 1875. The richly variegated composition of the population is reflected in the patient list of the first municipal midwife in Jakarta. In 1848 she assisted 100 deliveries, of which 73 were European women, 1 Armenian, 2 Javanese, 5 Chinese and 16 women of unknown nationality (W. Bosch 1854b:328, 330).

The sources also contain examples of the opposite situation: Europeans who allowed themselves to be treated by non-European healers. Eurasians sometimes benefited from treatment by a dukun, especially for diseases of the intestines (Waitz 1829:iv; Van Hien 1924:14). Even an official document like the Colonial Report ( $K V$ 1849:83) mentioned this in 1849, although it was generally scathing about the dukun. Apparently, people were aware that it was not the proper thing to do: 'even in wellto-do families' a European physician was retained 'for decency's sake', while people used Javanese medicines 'behind his back' (Kiewiet de Jonge 1911:283). We already noted that European women would turn to a dukun bayi for an abortion or to reposition the uterus to reduce the chance of pregnancy (Van der Burg 1882:70). The deliveries of most European women in the interior were assisted by a dukun bayi (Van der Burg 1882:92). Sometimes the husband declared that he was not aware of this because otherwise he would 'certainly have prevented such charlatanism' (Stevens 1856:64). Europeans also sought treatment for syphilis or diphtheria from Chinese healers (Van der Burg 1887:391; Vorderman 1890:2-3). In the case histories of (Indo-)Europeans who turned to non-European healers, the diseases were often ones which could not be helped by European medicines or procedures that European doctors could not or would not do.

\section{REGISTRATION}

One of the first forms of government intervention in health care in the Netherlands involved controlling the practice of medicine. The situation in the colony followed suit (Van der Burg 1882:340). Given the principle of indirect administration, it was logical for the colonial administration 
to control just the European medical market. Only those authorised to practise medicine, dentistry, midwifery or pharmacy in the Netherlands were authorised to do so in the Dutch East Indies (Ind. Stb. 1882 no. 97 art. 15). One could obtain this same authorisation in the East Indies by passing exams there (Ind. Stb. 1882 no. 97 art. 17-40). The practice of medicine by unauthorised persons was a punishable offence. ${ }^{101}$ This stipulation did not apply to Europeans providing assistance in the absence of a physician (Ind. Stb. 1882 no. 99), which occurred on a large scale. In addition, the government arranged who could run a private practice as a physician, midwife or apothecary. For example, although J. SchaddeleeHoogvelt was known to the government as the municipal midwife in Surabaya, she had to apply for permission in 1851 to practise there as a private midwife. In towns housing one or more apothecaries, physicians were not allowed to prepare or supply medicines (Ind. Stb. 1827 no. 68 art. 21). This seems to have been an anti-competition policy.

'The practice of Eastern healers is entirely free of any restricting stipulation', according to the Staatsblad van Nederlandsch Indië. ${ }^{102}$ The government was not always consistent because serious errors made by dukun treating indigenous patients were sometimes punished by the government. In 1872 a dukun was sentenced to 15 years of hard labour because a 15-month-old baby who was apparently possessed by the devil died of burn wounds after the dukun tried to drive the devil out of him (Idema 1934:314). A dukun who removed too large a part of the penis during circumcision was sentenced to three months of hard labour (Soemodirdjo 1909:15-9).

\section{HEALTH POLICY}

Although the government in principle did not concern itself with the health of the indigenous population, there was some form of health policy in certain fields, like combatting infectious diseases. In that case there was the obvious risk that Europeans could also become infected, and the government was responsible for their health. All European physicians, even the private ones, were obliged to inform the local administration immediately when an infectious disease broke out ( $K V$ 1849:82). During an epidemic, everyone was involved because the indigenous

101 GB 2-9-1847 no. 2, Bijblad 809; Ind. Stb. 1853 no. 68.

${ }_{102}$ Quotation in KV 1849:92; Ind. Stb. 1853 no. 99. 
population often called on Western doctors and medicines at that time. In 1848 in the regency of Jepara, the natives came from far and wide to visit the European physicians during an epidemic rather than the dukun, as the resident noted pointedly. To make matters worse, one of the two European physicians took ill, but luckily the local apothecary could replace him. The vaccinators stopped giving vaccinations and supplied medicines instead. ${ }^{103}$ During the cholera epidemic in 1849 , the population took the prescribed mixture in blind faith, although they were usually adverse to Western medicines, stated the Colonial Report $(K V$ 1851:54) with some pride.

Soon after the publication by Edward Jenner of his discovery of the smallpox vaccine in 1798 , the government began to vaccinate the indigenous population. In 1850 under the leadership of the vaccine superintendent, A.E. Wazklewicz, a new system was introduced, in which the population had to travel less far, and fewer but better paid vaccinators came to them. The government tried to reduce the resistance by employing penghulu (Islamic religious leader) as assistants. In the residency of Jakarta around 1850, six female vaccinators were hired because the indigenous women and marriageable girls did not want to be vaccinated by men. ${ }^{104}$ The female vaccinators had to be well trained because their work was difficult to monitor:

Another check cannot be done, as long as the parties concerned [husbands or fathers] cannot be persuaded to bring the vaccinated women and daughters to the municipal physician once in a while, which should meet with less resistance because no physical contact is necessary, and nothing needs to be revealed except for a small spot on the arm. ${ }^{105}$

Religious objections occurred frequently. In the residency of Bagelen, several indigenous leaders, who 'adhered to a purer Mohammedan teaching', opposed vaccination. They were reprimanded and threatened with dismissal if they did not cooperate with the next round: 'This

\footnotetext{
103 AV 1848, Archief Schoute Japara.

104 Appointment resolution was taken on 20-10-1849; it actually concerned formalisation after the fact because Head of the Medical Service Bosch had already decided on the appointment without prior authorisation, Archief Schoute Batavia.

${ }_{105}$ Letter from the head of the Medical Service to the resident of Batavia 21-6-1849 no. 350, Archief Schoute Batavia.
} 
warning had the most beneficial effect'. ${ }^{106}$ Strictly speaking, coercion was forbidden, but the regents were obliged to recommend vaccination and counteract the population's resistance (Ind. Stb. 1820 no. 22 art. 11). Apparently, this stipulation was so important that evasion was a reason for dismissal. Civil Medical Service inspector G. Luchtmans concluded in 1874 that coercion had never legally existed, but was exerted in practice (Winkler and Noordhoek Hegt 1906:CXX). Not attending a vaccination or booster visit was punished by the regency's court with a fine - in Banten this was five guilders - or 'equivalent amount of work without pay' (Winkler and Noordhoek Hegt 1906:LX). The indigenous elite in Yogyakarta generally had their children vaccinated, but they did not want to exert any influence on the ordinary Javanese 'as it may conflict with their religious beliefs'. ${ }^{107}$ Vaccination was evaded because of religious considerations and rumours of all sorts: vaccination made children weak and cowardly, or it was an attempt by the Dutch to label indigenous children with a magical mark so that they would later serve in the East Indies army (Boomgaard 2003:608; Van den Berge 1998:170). Elsewhere religious and political leaders considered vaccination a powerful instrument of the Dutch, and that is why they resisted. According to the resident of Banten, Mas Raie incited resistance against the smallpox vaccination in 1820 as a cover for his rebellion, which was soon put down (S. van Deventer 1866:30).

The many bachelors among all population groups in the East Indies made prostitution an accepted phenomenon, a necessary evil (Hesselink 1987:206). With the Reglement tot wering van de schadelijke gevolgen welke uit de prostitutie voortvloeijen (Regulation for the suppression of the damaging consequences derived from prostitution) (1852), the government hoped to counter the negative sequelae. The budget for combatting syphilis was also increased by 20,000 guilders (Borgers 1941:91). According to the regulation, prostitutes were obliged to register with the police and in principle undergo weekly examinations for syphilis by a physician -in practice this was usually once every two weeks. As the civil physician in Sidoarjo (Surabaya), Kohlbrugge (1903:2) inspected prostitutes five mornings a week, on average 200 per week. Infected women were admitted to the women's hospital next to the jail or in a special hospital for syphilitic women. Often the police made sure that they did not leave the

106 AV 1852, Archief Schoute Bagelen.

${ }_{107}$ AV 1851, Archief Schoute Djokjakarta. 


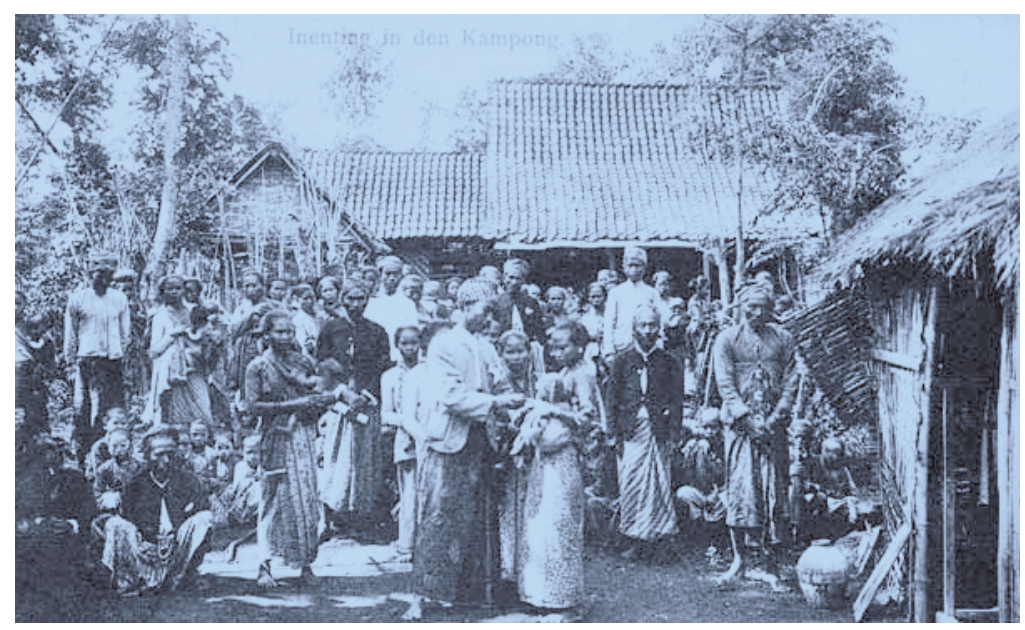

Vaccination in the kampong (photo collection KITLV 32745)

hospital. The soldiers were also examined weekly for signs of syphilis and other infectious diseases. ${ }^{108}$ If syphilis was found among the troops, they were punished heavily and confined to a hospital. They had to identify the woman who had infected them. ${ }^{109}$ Here the government clearly had no objection to exerting coercion. The high percentage of soldiers $(20 \%)$ with venereal diseases explains this attitude. ${ }^{110}$

Sick prisoners, forced labourers and beggars had a right to treatment by a health officer or another physician charged with the Civil Medical Service. If no European physician was available, the local authorities would call in a dukun (Ind. Stb. 1847 no. 53), but this was considered a second-rate option. This showed that the government felt responsible for the health of the natives, even if only a few of them, and provided some funds for their health care. Forced labourers were probably cared for because they were cheap sources of labour. The daily treatment of the patients in the beggars' infirmary in the district of Kendal (Semarang) was assigned to two dukun, who each received 10 guilders per month for this job (Schoute 1936:77). The dukun working in the prison in Bogor

\footnotetext{
108 Reglement op de Militaire Geneeskundige Dienst art. 57, Ludeking 1871:173.

109 Algemeene Orders 1862 no. 37, Ludeking 1871:174.

11о Wassink (1857:117) mentions a ratio of 1:4.9.
} 
received only five guilders. ${ }^{11}$ These payments were less than the 15 guilders for vaccinators. The government may have assumed that the dukun had income from normal work as well as this task. It is also possible that the government considered vaccination more important.

A final aspect of the colonial health policy was the stipulation that European civil servants with a monthly stipend of less than 150 guilders and their family members were entitled to free treatment by the physician charged with the Civil Medical Service.

Aside from the government, the sultan of Yogyakarta and the susuhunan of Surakarta implemented some form of health policy. For example, Pangeran Adipati Prang Wadhono paid three vaccinators with his own money. ${ }^{112}$ The sultan of Yogyakarta paid a large part of the expenses for the beggars' infirmary in his residency for years. ${ }^{113}$ In addition, in 1833 he had a main vaccinator and five standard vaccinators in service. ${ }^{114}$ In 1851 there were 11 , but after six months they still had not been paid. This 'appointment' reminds us of the compulsory labour (heerendienst) the lower class owed to the upper class. It was apparently not a coincidence that there was some health policy, particularly in the Principalities; the native administrators there did enjoy a certain amount of self-government.

\section{CONCLUDING REMARKS}

The medical market model assumes that sufferers have a choice, which is determined by the effectiveness of the caregiver and the treatment and the expense. In the Dutch East Indies around 1850, the sufferers hardly utilised the few options available. Partly this was due to the deficient infrastructure, but socio-cultural factors formed a more important barrier. The natives' concepts of health and disease meant that they did not trust Western medicine or doctors. The Europeans felt the same way about the reverse situation. This led to each population group in practice having its own market of medical goods and services. Sometimes, however,

\footnotetext{
11 Archief Schoute Buitenzorg, 1851.

112 Archief Schoute Soerakarta.

113 AV residency of Yogyakarta 1853, 1855, 1861, 1875, Archief Schoute Djokjakarta.

${ }_{114}$ Archief Schoute Djokjakarta 1833, 1837.
} 
sufferers availed themselves of the services of caregivers from another population group. This happened when a caregiver had a specific skill that the healer from one's own group lacked; for example, European physicians operated, and a dukun treated intestinal diseases and carried out abortions. Or during a fever epidemic, natives might resort to Western medicine and quinine in desperation. The Native and Chinese elites also allowed themselves to be treated by European doctors. Although these movements between members of different medical markets were exceptions to the general rule, they did produce a certain level of competition. European physicians examined successful treatments by sinse to apply them eventually to their own patients. It is understandable that sinse would consider this competition and want to keep their formulas secret. Surgery gained indigenous patients for European physicians because dukun did not operate, but the narcosis was used by competitors - in bad or good faith - to discredit surgery. The Europeans also competed with each other: the physicians wanted to uphold their monopoly on the use of instruments during deliveries and did not want midwives to get hold of them. In the field of indigenous herbs, there was a structural overlap: the herbs were often supplied by the Chinese and used by the indigenous, Chinese and European caregivers and sufferers.

The colonial policy hardly influenced the traffic on the medical markets. The legal classification of the population as established by the colonial administration was reflected in the health care sector: each population group had in principle its own medical market. The government wanted to regulate the supply side of the European medical market, but because neither the legal classification nor the regulations were watertight, they did not necessarily restrict free traffic between the different medical markets. The government left the indigenous medical market alone in principle, although regarding vaccination against smallpox, pressure, if not coercion, was exerted on the natives. Because it undermined the army's fighting capability, the government also forced prostitutes to be examined for infection with syphilis. In practice, many prostitutes were able to avoid this.

In the following chapters we shall see what position the graduates of the two medical schools occupied in the separate medical markets. They were Natives by birth, who had had a Western medical education with the intention of offering their services to their compatriots. 